\title{
Aqueous contamination during small incision cataract surgery: a lesson in study design
}

Endophthalmitis remains a small but definite risk during all forms of intraocular surgery and considerable effort has been and still is being expended by ophthalmologists throughout the world to minimise this risk because of the serious visual morbidity associated with such infection. The origin of the infecting organisms is predominantly from commensals on the ocular surface ${ }^{12}$ and, to a lesser extent, from airborne micro-organisms ${ }^{3}$ or other endogenous sources such as the genitourinary tract. It has been clearly demonstrated that viable organisms are introduced into the eye during cataract surgery, and bacteria may be isolated from aqueous in a quarter or more eyes undergoing extracapsular procedures, ${ }^{4-8}$ even when there has been surface disinfection with povidone iodine or preoperative topical antibiotics have been administered. 89 The reasons for the high rate of anterior chamber contamination during extracapsular surgery include the relatively large size of the wound, which is not self sealing, and generation of negative intraocular pressure, which lead to an influx of the surrounding, potentially contaminated irrigating fluids. The introduction of small incision cataract surgery should theoretically reduce these opportunities for intraocular contamination, but is this really the case in practice?

In this issue of the BfO, Manners et al (p 878) report a $20 \%$ incidence of aqueous contamination in small incision cataract surgery, which is similar to their previous study of extracapsular surgery. ${ }^{8}$ The authors have, therefore, concluded that small incision surgery confers 'no proved advantage' over extracapsular surgery in reducing bacterial contamination of the aqueous. However, in two larger studies of 200 and 230 patients respectively, Egger et al 7 found that aqueous contamination was significantly less with phacoemulsification than with conventional extracapsular surgery. It is very likely, therefore, that the study described here did not have the power to detect a small but real difference in contamination rates with the different surgical techniques. A $60 \%$ reduction in contamination that is, only five positive cultures, would have been required in this study to achieve statistical significance at the $5 \%$ level.

How important are these levels of aqueous contamination and are they clinically relevant? In the series described by Egger $e t a l^{6}$ and Manners et al, the numbers of bacteria detected were very small. In only one of the 10 positive cases in the current series reported by Manners et al was more than a single colony of bacteria grown on a culture plate, and in their previous study, only two of the nine positive culture plates had two or more bacterial colonies. The clinical significance of these low levels of contamination with regard to the risk of subsequent endophthalmitis is very difficult to determine, but it is evident that the majority of eyes successfully eradicate the low levels of intraoperative contamination through the bactericidal properties of aqueous humour which we do not yet fully understand.

Prophylactic antibiotics in irrigating fluids have been shown to reduce the incidence of positive aqueous cultures during phacoemulsification surgery. ${ }^{10}$ Although the contamination rate of $5 \%$ in the control groups of this latter study is much lower than other reports of extracapsular surgery, ${ }^{6-8}$ this finding does lend further indirect support for small incision surgery.

How do these observations translate into better clinical practice? There are now several very large but poorly controlled series describing the use of antibiotics - for example, gentamicin or vancomycin either alone or in combination, in irrigating solutions in cataract surgery where endophthalmitis rates of 1 in 10000 or lower have been reported. ${ }^{11} 12$ The incorporation of antibiotics into irrigating solutions for all patients undergoing intraocular surgery inevitably results in many patients receiving apparently unnecessary treatment, with obvious financial implications, but what price are we prepared to pay to reduce the risk of endophthalmitis to the absolute minimum?

Whipps Cross Hospital,

HAMISH TOWLER

London E11 1NR

1 Weber DJ, Hoffman KL, Thoft RA, Baker AS. Endophthalmitis following intraocular lens implantation: report of 30 cases and review of the literature. Rev Infect Dis 1986; 8: 12-20.

2 Speaker MG, Milch FA, Shah MK, Eisner W, Kreisworth BN. The role of external bacterial flora in the pathogenesis of acute postoperative endophthalmitis. Ophthalmology 1991; 98: 639-49.

3 Spencer SR, Dealler SF, Hassett PD, Todd NJ, Hawkey PM, Noble BA. Bacterial contamination of intraocular lenses: the source of the bacteria. Eye 1989; 3: 685-9.

4 Sherwood DR, Rich WJ, Jacob JS, Hart RJ, Fairchild YL. Bacterial contamination of intra-ocular and extra-ocular fluids during extra-capsular cataract extraction. Eye 1989; 3: 308-12.

5 Dickey JB, Thompson KD, Jay WM. Anterior chamber aspirate cultures after uncomplicated cataract surgery. Am f Ophthalmol 1991; 112: 272-82.

6 Egger SF, Huber-Spitz V, Scholda C, Schneider B, Grabner G. Bacterial contamination during extracapsular surgery. Prospective study on 200 consecutive patients. Ophthalmologica 1984; 208: 77-81.

7 Egger SF, Huber-Spitz V, Skorpik C, Weghaupt H, Scholda C, ArockerMettinger E, et al. Different techniques of extracapsular cataract extraction: bacterial contamination during surgery. Prospective study on 230 consecutive patients. Graefes Arch Clin Exp Ophthalmol 1994; 232: 308-11.

8 Chitkara DK, Manners T, Chapman F, Stoddart MG, Hill D, Jenkins D. Lack of effect of preoperative norfloxacin on bacterial contamination of anterior chamber aspirates after cataract surgery. $B r \mathcal{F}$ Ophthalmol 1994; anterior cham

9 Isenberg SJ, Apt L, Yoshimori R, Khwarg S. Chemical preparation of the eye in ophthalmic surgery: IV. Comparison of povidone-iodine on the conjunctiva with a prophylactic antibiotic. Arch Ophthalmol 1985; 103: 1340-2.

10 Henry JC, Rozas D. Bacterial growth from anterior chamber aspirates using different irrigating solutions in phacoemulsification. Invest Ophthalmol Vis Sci 1994; 34: 884

11 Gills JP. Filters and antibiotics in irrigating solutions for cataract surgery. 7 Cataract Refract Surg 1991; 17: 385.

12 Gimbel HV, Sun R, DeBrof BM. Prophylactic antibiotics during cataract surgery: the incidence of endophthalmitis and corneal endothelial cell loss. Eur $\mathcal{F}$ Cataract Refract Surg 1994; 6: 280-5. 